\title{
Substitusi Medium Sintetik dengan Pupuk Daun, Air Kelapa dan Ekstrak Nabati pada Subkultur Anggrek Cattleya pastoral Innocence secara In Vitro
}

\author{
DOI 10.18196/pt.2014.031.115-124
}

\author{
Etty Handayani* dan Bambang Heri Isnawan \\ Program Studi Agroteknologi, Fakultas Pertanian, Universitas Muhammadiyah Yogyakarta, \\ Jl. Lingkar Selatan, Kasihan, Bantul, Yogyakarta 55183, Indonesia Telp. 0274387656 , \\ *Corresponding author: e-mail:etty.umy@gmail.com
}

\begin{abstract}
ABSTRAK
Penelitian ini bertujuan untuk membandingkan dan mengetahui medium pupuk daun Hyponex dan ekstrak nabati yang dapat memberikan pertumbuhan terbaik pada subkultur anggrek Cattleya pastoral innocence. Penelitian ini telah dilaksanakan di Laboratorium Kultur Jaringan Fakultas Pertanian Universitas Muhammadiyah Yogyakarta. Penelitian menggunakan metode percobaan laboratorium menggunakan rancangan faktor tungggal dengan 9 perlakuan yang disusun dalam Rancangan Acak Lengkap (RAL) dengan 8 ulangan. Perlakuan - perlakuan terdiri atas medium Vacin \& Went + NAA 0,5 ppm + BAP 3 ppm, Hyponex hijau 3 g/l, Hyponex hijau 3 g/l + Tauge 150 g/l, Hyponex hijau 3 g/l + Tomat 150 g/l, Hyponex hijau 3 g/l + Alpukat 150 g/l, Hyponex merah $3 \mathrm{~g} / \mathrm{l}$, Hyponex merah $3 \mathrm{~g} / \mathrm{l}+$ Tauge $150 \mathrm{~g} / \mathrm{l}$, Hyponex merah $3 \mathrm{~g} / \mathrm{l}+$ Tomat $150 \mathrm{~g} / \mathrm{ll}$, Hyponex merah $3 \mathrm{~g} / \mathrm{l}+$ alpukat $150 \mathrm{~g} / \mathrm{l}$. Masing - masing perlakuan pupuk daun ditambah pisang ambon $150 \mathrm{~g} / \mathrm{l}$ dan air kelapa $150 \mathrm{ml} / \mathrm{l}$. Hasil penelitian menunjukan bahwa medium pupuk daun Hyponex dan ekstrak nabati mampu menggantikan medium Vacin \& Went dalam subkultur anggrek Cattleya pastoral innocence secara in vitro untuk tinggi tanaman dan jumlah tunas. Medium pupuk Hyponex merah dan bahan alami pisang ambon $150 \mathrm{~g} / \mathrm{l}$ dan air kelapa $150 \mathrm{~g} / \mathrm{l} \mathrm{memberikan} \mathrm{pengaruh} \mathrm{yang} \mathrm{lebih} \mathrm{baik} \mathrm{terhadap} \mathrm{tinggi} \mathrm{tana-}$ man, jumlah daun dan jumlah tunas.

Kata kunci: Anggrek Cattleya pastoral innocence, Pupuk daun, Ekstrak nabati
\end{abstract}

\begin{abstract}
A research was perfomed to find the proper of coconut water and natural ekstracts combined with Hyponex medium that compared with Vacin \& Went medium. This research has been done at Tissue Culture Laboratory, Agricultural Faculty, Muhammadiyah University of Yogyakarta. The method of this research was arranged in Randomized Complete Design with 9 treatments and 8 replications. The treatments were VW + NAA 0,5 ppm + BAP 3 ppm, green Hyponex $3 \mathrm{~g} / \mathrm{ll}$ green Hyponex $3 \mathrm{~g} / \mathrm{l}+$ bean sprouts $150 \mathrm{~g} / \mathrm{l}$, green Hyponex $3 \mathrm{~g} / \mathrm{l}+$ tomatoes $150 \mathrm{~m} / / /$, green Hyponex $3 \mathrm{~g} / \mathrm{l}+$ avocado $150 \mathrm{~g} / \mathrm{l}$, red Hyponex $3 \mathrm{~g} / \mathrm{l}$, red Hyponex $3 \mathrm{~g} / \mathrm{l}+$ bean sprouts $150 \mathrm{~g} / \mathrm{l}$, red Hyponex $3 \mathrm{~g} / \mathrm{l}+$ tomatoes $150 \mathrm{ml} / \mathrm{ll}$, red Hyponex $3 \mathrm{~g} / \mathrm{l}+$ avocado $150 \mathrm{~g} / \mathrm{l}$. The each of Hyponex mediums were given with bananas $150 \mathrm{~g} / \mathrm{l}$ and coconut water $150 \mathrm{~m} / 1 /$. The result of this research showed that Hyponex mediums combined with natural ekstract was not signicicantly with Vacin \& Went medium to high and shoot growth. Red Hyponex medium $3 \mathrm{~g} / \mathrm{l}$ combined bananas $150 \mathrm{~g} / \mathrm{l}$ and coconut water $150 \mathrm{~m} / / /$ resulted the best high, leaf and shoot in tissue culture Cattleya pastoral innocence orchid.

Keywords: Cattleya pastoral innocence, Foliar fertilizer, Natural extract
\end{abstract}

\section{PENDAHULUAN}

Bunga anggrek dikenal terutama karena bentuk bunganya yang indah dan dapat bertahan lama. Dilihat dari potensi pasar pada tahun 2000-2004 omzet penjualan anggrek mengalami peningkatan sekitar 53,4\%. Namun produksi dalam negeri belum mampu memenuhi permintaan pasar dalam negeri. Hal ini dapat dilihat dari volume impor bunga anggrek di Jakarta yang rata-rata setiap bulan mengimpor bunga anggrek 50-100 boks dan setiap boks berisi 1000 tanaman (Anonim, 2004).
Jenis anggrek yang ada di Indonesia sangat beragam, salah satunya adalah anggrek genus Cattleya. Cattleya ini diburu bukan hanya untuk tujuan pelestarian dan pengembangan penelitian serta koleksi tanaman hias tetapi juga untuk tujuan komersial. Cattleya mendapat julukan "ratu anggrek" karena memiliki bunga yang berukuran besar. Cattleya tergolong anggrek epifit dan termasuk anggrek yang berumbi semu (pseudobulb). Berdasarkan ciri morfologisnya Cattleya termasuk anggrek simpodial dimana anggrek tersebut 
mempunyai pertumbuhan ujung batang terbatas (Anonim, 2002)

Perkembangbiakan tanaman anggrek dapat dilakukan secara vegetatif ataupun generatif. Perkembangbiakan secara vegetatif dilakukan dengan repotting (pemisahan rumpun) sedangkan perkembangbiakan secara generatif yaitu dengan menggunakan biji. Perkembangbiakan secara generatif membutuhkan waktu yang lama karena embrio atau biji anggrek bukan biji yang sempurna dan tidak mempunyai cadangan makanan untuk pertumbuhan embrionya. Oleh karena itu untuk mengecambahkan atau menumbuhkan biji anggrek mempunyai tingkat kesulitan yang tinggi. Adanya kendala perbanyakan tanaman anggrek, maka perbanyakan anggrek dengan biji melalui kultur in vitro merupakan teknik perbanyakan yang tepat (Susilo, 1990)

Salah satu kegiatan yang terdapat dalam kultur in vitro adalah subkultur yaitu pemindahan anggrek dari medium lama ke medium baru yang dilaksanakan secara aseptis di dalam entkas atau ruang penabur. Subkultur dilakukan apabila pertumbuhan anggrek dalam medium lama sudah saling berdesakan dan berebut unsur hara yang semakin menipis. (Hendaryono, 1996)

Medium yang digunakan dalam kultur in vitro anggrek pada umumnya adalah medium $\mathrm{Va}$ cin \& Went dengan penambahan air kelapa 150 g/1, 0,5-1 ppm NAA dan 1-3 ppm BAP. Medium tanam berupa bahan-bahan kimia seperti komposisi medium Vacin \& Went dan hormon sintetik membutuhkan biaya yang tidak sedikit. Untuk menghemat biaya, medium Vacin \& Went dapat digantikan dengan formulasi yang telah ada yaitu dengan menggunakan pupuk daun 3-4 gram sebagai pengganti sumber hara dan ditambahkan ekstrak nabati sebagai pengganti zat-zat organik. Pupuk daun mengandung unsur hara makro dan unsur hara mikro yang sangat dibutuhkan dalam pertumbuhan tanaman sehingga peranannya diharapkan dapat menggantikan medium kultur yang mahal. Peran zat pengatur tumbuh sangat diperlukan dalam kultur in vitro, tetapi zat tersebut dapat digantikan dengan bahan-ekstrak nabati seperti air kelapa, ekstrak pisang, ekstrak kentang, ekstrak jagung dan ekstrak kapri. Bahan alami merupakan sumber gula, vitamin, asam amino dan zat pengatur tumbuh.

Penelitian ini bertujuan untuk mengetahui pupuk daun dan macam ekstrak nabati yang mampu menggantikan medium VW + NAA 0,5 ppm + BAP 3 ppm dan mengetahui pupuk daun dan ekstrak nabati yang memberikan pertumbuhan terbaik pada subkultur anggrek Cattleya pastoral innocence. Manfaat penelitian ini yaitu diharapkan dapat menggantikan medium kultur in vitro yang mahal dengan menggunakan pupuk daun dan bahan-ekstrak nabati sehingga menghemat biaya yang digunakan.

\section{BAHAN DAN METODE}

Penelitian dilakukan di Laboratorium Kultur Jaringan Fakultas Pertanian Universitas Muhammadiyah Yogyakarta. Penelitian dilaksanakan dengan metode percobaan laboratorium menggunakan rancangan faktor tunggal 9 perlakuan yang disusun dalam RAL. Masing-masing perlakuan diulang delapan kali. Dengan demikian total unit perlakuan adalah 9 x $8=72$ botol.

Perlakuan yang dicobakan adalah sebagai berikut:

A: VW + NAA 0,5 ppm + BAP 3 ppm (kontrol)

B: Hyponex Hijau $3 \mathrm{~g} / 1$

C: Hyponex Hijau $3 \mathrm{~g} / 1+$ Tauge $150 \mathrm{~g} / 1$

D: Hyponex Hijau $3 \mathrm{~g} / \mathrm{l}+$ Tomat $150 \mathrm{~g} / \mathrm{l}$

E: Hyponex Hijau $3 \mathrm{~g} / \mathrm{l}+$ Alpukat $150 \mathrm{~g} / \mathrm{l}$

F: Hyponex Merah $3 \mathrm{~g} / 1$

G: Hyponex Merah $3 \mathrm{~g} / \mathrm{l}+$ Tauge $150 \mathrm{~g} / \mathrm{l}$

$\mathrm{H}$ : Hyponex Merah $3 \mathrm{~g} / \mathrm{l}+$ Tomat $150 \mathrm{~g} / \mathrm{l}$

I : Hyponex Merah $3 \mathrm{~g} / 1+$ Alpukat $150 \mathrm{~g} / 1$ 
Masing - masing perlakuan medium pupuk daun ditambahkan ekstrak pisang $150 \mathrm{~g} / \mathrm{l}$ dan air kelapa $150 \mathrm{ml} / \mathrm{l}$. Variabel yang diamati meliputi: Tinggi tanaman (cm), Jumlah tunas, Jumlah daun, Persentase planlet browning (\%) dan Warna planlet. Data dianalisis menggunakan sidik ragam dengan taraf kesalahan $5 \%$. Kemudian dilakukan uji lanjut menggunakan Kontras Ortogonal pada taraf kesalahan $5 \%$. Adapun pertumbuhan tanaman selama 10 minggu (tinggi tanaman, jumlah daun dan jumlah tunas) disajikan dalam bentuk histogram dan grafik.

\section{HASIL DAN PEMBAHASAN}

Tinggi Tanaman, Jumlah Daun dan Jumlah Tunas

Rerata tinggi tanaman, jumlah daun dan jumlah tunas anggrek Cattleya pastoral innocence disajikan pada tabel 1 .

Tabel 1. Rerata Tinggi Tanaman, Jumlah Daun dan Jumlah Tunas Anggrek Cattleya pastoral Innocence Umur 10 Minggu

\begin{tabular}{|c|c|c|c|c|c|}
\hline \multicolumn{2}{|c|}{$\begin{array}{c}\text { Tinggi Tanaman } \\
\text { Perbandingan Berkelompok }\end{array}$} & \multicolumn{2}{|c|}{$\begin{array}{l}\text { Jumlah Daun } \\
\text { Perbandingan Berkelompok }\end{array}$} & \multicolumn{2}{|c|}{$\begin{array}{l}\text { Jumlah Tunas } \\
\text { Perbandingan Berkelompok }\end{array}$} \\
\hline$A$ & BCDEFGH I & $A$ & BCDEFGHI & $A$ & $\mathrm{BCDEFGHI}$ \\
\hline $1,400 \mathrm{a}$ & $1,339 a$ & $5,125 \mathrm{a}$ & $2,912 b$ & $1,875 \mathrm{a}$ & $1,781 \mathrm{a}$ \\
\hline$B C D E$ & FGHI & $B C D E$ & F G HI & $B C D E$ & FGHI \\
\hline $1,303 c$ & $1,375 c$ & $2,718 c$ & $3,093 c$ & $1,812 \mathrm{c}$ & $1,750 \mathrm{c}$ \\
\hline B & $C D E$ & B & $C D E$ & B & $C D E$ \\
\hline $1.538 \mathrm{e}$ & $1.224 \mathrm{f}$ & $3,500 \mathrm{e}$ & $2,458 \mathrm{e}$ & $2,750 \mathrm{e}$ & $1,500 \mathrm{f}$ \\
\hline C & $D E$ & C & $\mathrm{DE}$ & C & $D E$ \\
\hline $1,362 \mathrm{~g}$ & $1,156 \mathrm{~g}$ & $2,500 \mathrm{~g}$ & $2,437 \mathrm{~g}$ & $1,875 \mathrm{~g}$ & $1,312 \mathrm{~g}$ \\
\hline D & $E$ & D & $E$ & D & $E$ \\
\hline $1,012 \mathrm{i}$ & $1,300 \mathrm{i}$ & $2,375 \mathrm{i}$ & $2,500 \mathrm{i}$ & $1,625 \mathrm{i}$ & $1,000 \mathrm{i}$ \\
\hline $\mathrm{F}$ & GHI & $\mathrm{F}$ & GHI & $\mathrm{F}$ & GHI \\
\hline $1,625 \mathrm{k}$ & 1,2921 & $5,625 \mathrm{k}$ & 2,251 & $3,125 \mathrm{k}$ & 1,291 I \\
\hline G & $\mathrm{HI}$ & G & $\mathrm{HI}$ & G & $\mathrm{HI}$ \\
\hline $1,400 \mathrm{~m}$ & $1,237 \mathrm{~m}$ & $3,625 \mathrm{~m}$ & $1.562 n$ & $1,875 \mathrm{~m}$ & $1,000 n$ \\
\hline $\mathrm{H}$ & I & H & I & H & I \\
\hline 1,3500 & 1,1250 & 1,8750 & 1,2500 & 1,0000 & 1,0000 \\
\hline
\end{tabular}

Keterangan: Angka yang diikuti huruf yang sama dalam baris menunjukan tidak berbeda nyata berdasarkan uji kontras orthogonal pada taraf kesalahan $5 \%$. Masing - masing perlakuan medium pupuk daun ditambah ekstrak pisang $150 \mathrm{~g} / \mathrm{l}$ dan air kelapa $150 \mathrm{ml} / \mathrm{l}$
Tabel 1 menunjukkan tidak ada perbedaan nyata antar perlakuan kontrol (VW + NAA 0,5 ppm + BAP 3 ppm) dengan perlakuan medium pupuk daun dan pemberian air kelapa dan ekstrak nabati terhadap tinggi tanaman dan jumlah tunas (perbandingan kontras ke-1). Komposisi medium VW mengandung unsur hara makro dan mikro yang dilengkapi zat pengatur tumbuh NAA 0,5 ppm dan BAP 3 ppm yang mendukung pertumbuhan tinggi dan tunas tanaman anggrek Cattleya pastoral innocence. Medium pupuk daun Hyponex baik hijau maupun merah yang ditambahkan zat pengatur tumbuh alami juga menghasilkan rerata tinggi tanaman dan jumlah tunas tidak berbedanyata dengan medium VW + NAA 0,5 ppm + BAP 3 ppm. Hal ini disebabkan ketersediaan unsur hara terutama nitrogen di dalam pupuk daun Hyponex hijau dan Hyponex merah mampu memenuhi kebutuhan tanaman anggrek Cattleya pastoral innocence dalam pertumbuhan vegetatif. Terpenuhinya unsur hara makro dan mikro dalam medium pupuk daun memungkinkan tanaman anggrek Cattleya pastoral innocence tumbuh. Disamping ketersediaan unsur hara, keberadaan zat pengatur tumbuh baik sintetik ataupun alami dalam medium berpengaruh terhadap pertumbuhan tanaman. Akan tetapi pada parameter jumlah daun medium VW memberikan pengaruh nyata lebih banyak dibandingkan perlakuan medium pupuk daun dan penambahan ekstrak nabati. Kandungan garam-garam anorganik dan zat pengatur tumbuh yang terdapat pada medium Vacin \& Went lebih mudah diserap dan diikat oleh tanaman dalam organogenesis membentuk daun.

Penggunaan pupuk daun Hyponex hijau dan merah pada subkultur anggrek Cattleya pastoral innocence menunjukkan pengaruh tidak berbeda nyata terhadap tinggi tanaman, jumlah daun dan jumlah tunas (perbandingan kontras ke-2). 
Pupuk daun Hyponex hijau dan merah berbeda dalam hal komposisi N-P-K. Pupuk Hyponex hijau mempunyai perbandingan unsur N-PK 20:20:20 sedangkan pada Hyponex merah mempunyai perbandingan unsur N-P-K 25:5:20. Dalam pertumbuhan vegetafif tanaman, unsur nitrogen lebih dibutuhkan dalam jumlah yang besar dibandingkan unsur fosfor. Unsur nitrogen penting dalam pembentukan hijau daun sedangkan unsur fosfor berperan dalam proses pembungaan dan pembuahan. Dalam subkultur, tanaman anggrek Cattleya pastoral innocence masih dalam fase vegetatif sehingga unsur nitrogen lebih dibutuhkan dibanding unsur fosfor. Perbedaan unsur nitrogen pada Hyponex hijau dan merah yang tidak terlalu besar mengakibatkan rerata tinggi tanaman, jumlah daun dan jumlah tunas yang cenderung sama.

Pada medium pupuk daun Hyponex hijau dengan pemberian pisang ambon dan air kelapa menunjukkan hasil yang lebih baik terhadap tinggi tanaman dan jumlah tunas dari pada penambahan tauge, tomat atau alpukat pada medium tersebut (perbandingan kontras ke-3). Hal ini disebabkan ekstrak nabati yang diberikan tidak terlalu banyak, sehingga akan lebih mendukung bagi pertumbuhan tanaman. Pemberian tauge, tomat dan alpukat pada medium pupuk daun Hyponex hijau justru menghasilkan rerata tinggi tanaman dan jumlah tunas yang lebih rendah. Adanya coumarin yang terdapat dalam tomat dapat meningkatkan oksidasi fenol yang justru akan menghambat pembelahan sel. Ekstrak tauge mempunyai kandungan auksin yang tinggi, selain itu fosfor organik pada tauge lebih banyak dibandingkan ekstrak nabati lainnya. Kebanyakan fosfor dalam medium dapat menghambat pertumbuhan tanaman. Hal ini disebabkan adanya persaingan penyerapan unsur lainnya seperti Zn dan Fe. Penambahan alpukat juga memberikan pengaruh negatif untuk pertumbuhan anggrek. Dengan penambahan alpukat, medium menjadi lebih padat dan kandungan air menjadi berkurang. Padahal air memegang peranan penting sebagai pelarut unsur hara dan material organik seperti karbohidrat. Akibatnya tanaman tidak mampu menyerap unsur yang dibutuhkan untuk pertumbuhannya. Pada parameter jumlah daun menunjukan tidak ada pengaruh nyata antara perlakuan yang hanya diberi ekstrak nabati pisang ambon dan air kelapa pada Hyponex hijau dengan perlakuan yang ditambahkan tauge, tomat dan alpukat. Untuk organogenesis membentuk daun dibutuhkan unsur hara dan zat pengatur tumbuh yang cukup. Diduga kandungan nitrogen pada Hyponex hijau belum mendukung tanaman dalam membentuk daun. Selain itu karbohidrat yang terdapat pada pisang ambon terutama digunakan pada fase vegetatif dimana sebagian besar karbohidrat untuk pembelahan sel dan diferensiasi sel.

Pada perbandingan kontras ke-4 Penambahan tauge menghasilkan rerata tinggi tanaman, jumlah daun dan jumlah tunas tidak berbedanyata dengan penambahan tomat dan alpukat pada pupuk Hyponex hijau + pisang ambon + air kelapa. Hal ini diduga pengaruh zpt terutama sitokinin yang digunakan untuk pembelahan sel sudah diperoleh dari ekstrak pisang dan air kelapa.

Pada penambahan tomat atau alpukat pada pupuk Hyponex hijau menghasilkan pengaruh yang sama terhadap tinggi tanaman, jumlah daun dan jumlah tunas (perbandingan kontras ke-5). Hal ini disebabkan kandungan zat pengatur tumbuh yang hampir sama pada tomat dan alpukat yaitu adanya etilen yang justru menghambat pertumbuhan.

Pada perbandingan kontras ke-6 medium pupuk daun Hyponex merah yang ditambahkan ekstrak nabati pisang ambon dan air kelapa 
memberikan pengaruh nyata terhadap tinggi tanaman, jumlah daun dan jumlah tunas daripada penambahan ekstrak lainnya pada medium pupuk daun tersebut (tabel 1). Pertumbuhan tinggi tanaman diperoleh karena adanya pembelahan sel dan sudah dapat dipengaruhi oleh sitokinin yang terdapat pada pisang ambon dan air kelapa yang memacu pemanjangan sel dan didukung karbohidrat yang tinggi pada ekstrak pisang sehingga memberikan hasil yang optimum. Pemberian ekstrak nabati tauge, tomat dan alpukat justru menghambat pertumbuhan tinggi tanaman. Hal tersebut diakibatkan bahan organik yang terlalu tinggi pada medium dan tanaman kurang mampu beradaptasi pada medium tersebut. Rerata jumlah daun dan jumlah tunas (tabel 1) menunjukkan bahwa perlakuan Hyponex merah yang ditambahkan ekstrak nabati pisang ambon dan air kelapa menghasilkan rerata jumlah daun dan tunas lebih banyak dibandingkan penambahan ekstrak nabati yang lebih banyak pada medium tersebut. Hal ini berarti medium mampu menumbuhkan tanaman tidak tergantung pada kelengkapan bahan yang digunakan, akan tetapi lebih mengarah pada ketepatan baik macam bahan maupun jumlahnya. Kemampuan jaringan tanaman untuk menyerap zpt pada medium Hyponex merah yang ditambahkan pisang ambon dan air kelapa lebih mendorong sel pada organ tunas dalam deferensiasi membentuk daun dibandingkan penambahan ekstrak nabati yang lebih banyak.

Penambahan tauge pada medium Hyponex merah yang dikombinasikan pisang ambon dan air kelapa memberikan pengaruh sama dengan penambahan tomat dan alpukat terhadap tinggi tanaman (perbandingan kontras ke-7). Hal ini disebabkan energi yang dibutuhkan untuk pertumbuhan tinggi tanaman sudah diperoleh dari karbohidrat pisang ambon dan adanya hormon sitokinin pada pisang dan air kelapa. Pada parameter jumlah daun dan tunas ekstrak tauge yang ditambahkan pada medium Hyponex merah + pisang ambon + air kelapa memberikan pengaruh jumlah daun dan tunas nyata lebih banyak dibandingkan perlakuan Hyponex merah dengan penambahan tomat dan alpukat. Hal ini disebabkan perbedaan jenis zat pengatur tumbuh. Auksin yang terdapat pada tauge merupakan zpt yang mampu merangsang pembelahan sel yang mendukung pembentukan daun dan tunas. Meskipun tomat dan alpukat juga memiliki auksin, akan tetapi ekstrak nabati tersebut lebih dominan zat pengatur tumbuh etilen, hal ini disebabkan tomat dan alpukat yang digunakan dalam kondisi masak sehingga produksi etilennya meningkat, dimana fungsi etilen adalah sebagai inhibitor.

Pemberian tomat atau alpukat pada medium pupuk daun Hyponex merah memberikan pengaruh yang sama terhadap tinggi tanaman, jumlah daun dan jumlah tunas (perbandingan kontras ke-8). Kemampuan jaringan tanaman dalam menyerap bahan organik pada medium kurang sempurna akibat etilen yang tinggi pada medium tersebut. Coumarin yang terdapat pada tomat ternyata mempunyai sifat antagonis terhadap IAA dan menghambat pembelahan dan pembesaran sel. Selain itu ZPT yang terdapat dalam medium terlalu banyak sehingga mengalami oksidasi, detoksifikasi, pengikatan oleh asam amino, pengikatan oleh gula yang mengurangi aktifitas dari ZPT tersebut.

Pemberian ekstrak alami sebagai sebagai pengganti zat pengatur tumbuh sangat mempengaruhi pertumbuhan tanaman anggrek. Pada perlakuan dengan kombinasi ekstrak nabati yang terlalu banyak justru akan menghambat pertumbuhan tanaman. Hal ini disebabkan zat pengatur tumbuh lebih banyak dari yang dibutuhkan tana- 
man, sehingga tanaman tidak mampu beradaptasi pada medium yang baru sehingga pertumbuhan tanaman akan terganggu.

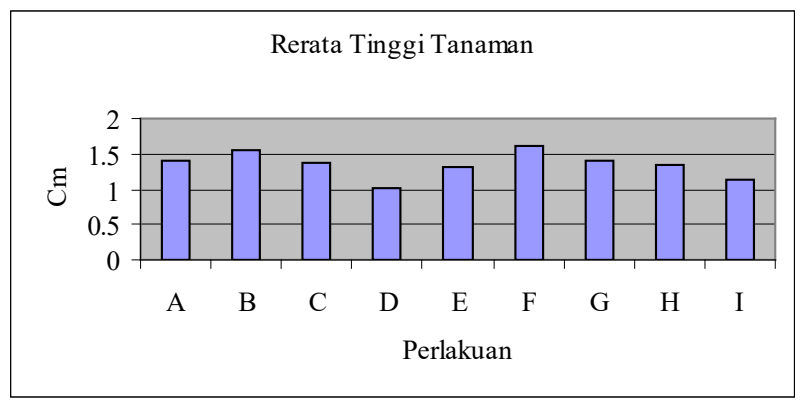

Gambar 1. Histogram tinggi tanaman anggrek Cattleya pastoral Innocence umur 10 minggu

\section{Keterangan:}

A: VW + NAA 0,5 ppm + BAP 3 ppm (kontrol) F: Hyponex Merah $3 g / l$

B: Hyponex Hijau $3 \mathrm{~g} / \mathrm{l} \quad \mathrm{G}$ : Hyponex Merah $3 \mathrm{~g} / \mathrm{l}+$ Tauge $150 \mathrm{~g} / \mathrm{l}$

C: Hyponex Hijau $3 \mathrm{~g} / \mathrm{l}+$ Tauge $150 \mathrm{~g} / \mathrm{l} \quad$ H: Hyponex Merah $3 \mathrm{~g} / \mathrm{l}+$ Tomat $150 \mathrm{~g} / \mathrm{l}$

D: Hyponex Hijau $3 \mathrm{~g} / \mathrm{l}+$ Tomat $150 \mathrm{~g} / \mathrm{l} \quad$ I: Hyponex Merah $3 \mathrm{~g} / \mathrm{l}+$ Alpukat $150 \mathrm{~g} / \mathrm{l}$

E: Hyponex Hijau $3 \mathrm{~g} / \mathrm{l}+$ Alpukat $150 \mathrm{~g} / \mathrm{l}$

Masing - masing perlakuan medium pupuk daun ditambah ekstrak pisang $150 \mathrm{~g} / \mathrm{l}$ dan air kelapa $150 \mathrm{ml} / \mathrm{l}$.

Berdasarkan gambar 1 diketahui bahwa perlakuan Hyponex merah dengan penambahan pisang ambon $150 \mathrm{~g} / \mathrm{l}$ dan air kelapa $150 \mathrm{ml} / 1$ memberikan rerata tinggi tanaman yang lebih baik dibandingkan perlakuan yang lain termasuk medium VW + NAA 0,5 ppm + BAP 3 ppm. Hal ini disebabkan kandungan unsur hara terutama nitrogen mampu menunjang pertumbuhan tinggi tanaman, selain itu ketepatan konsentrasi zat pengatur tumbuh yang terdapat pada medium akan merangsang pemanjangan sel.

Pertumbuhan tinggi tanaman diamati dengan mengukur tinggi tanaman setiap minggu selama sepuluh minggu. Hasil pengamatan terhadap pertumbuhan tinggi tanaman tersaji pada gambar 2 .

Berdasarkan gambar 2. diketahui bahwa pertumbuhan tinggi tanaman sudah mulai terjadi pada minggu ke 2 dan terus mengalami peningkatan yang besar sampai minggu ke 10. Hal ini karena unsur hara yang terdapat dalam medium masih banyak dan dimanfaatkan tanaman ang- grek Cattleya pastoral innocence untuk beradaptasi pada medium yang baru serta untuk meningkatkan pertumbuhannya antara lain memacu tinggi tanaman, sedang pada minggu berikutnya pertumbuhan tinggi tanaman cenderung stabil. Diduga tanaman sudah dapat beradaptasi dengan medium yang baru, selain itu dimungkinkan unsur hara yang terkandung pada masing-masing medium sudah mulai berkurang sehingga peningkatan pertambahan tinggi nampak seimbang.

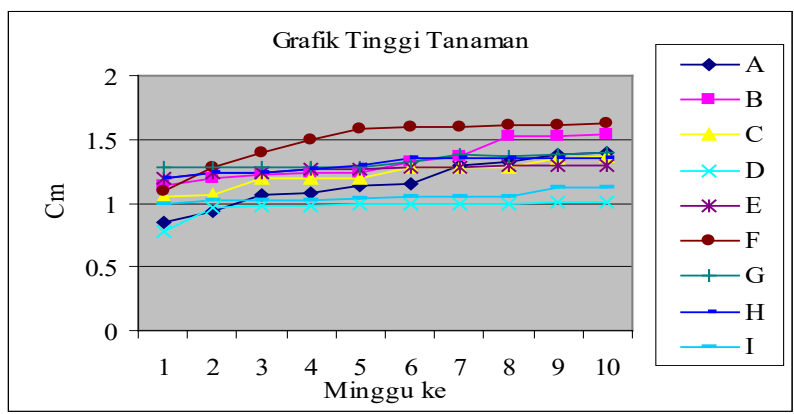

Gambar 2. Grafik tinggi tanaman anggrek Cattleya pastoral Innocence selama 10 minggu

Keterangan:

A: VW + NAA 0,5 ppm + BAP 3 ppm (kontrol) F: Hyponex Merah $3 \mathrm{~g} / \mathrm{l}$

B: Hyponex Hijau $3 \mathrm{~g} / \mathrm{l}$

C: Hyponex Hijau $3 \mathrm{~g} / \mathrm{l}+$ Tauge $150 \mathrm{~g} / \mathrm{l}$
D: Hyponex Hijau $3 \mathrm{~g} / \mathrm{l}+$ Tomat $150 \mathrm{~g} / \mathrm{l}$

D: Hyponex Hijau $3 \mathrm{~g} / \mathrm{l}+$ Tomat $150 \mathrm{~g} / \mathrm{l}$
E: Hyponex Hijau $3 \mathrm{~g} / \mathrm{l}+$ Alpukat $150 \mathrm{~g} / \mathrm{l}$

G: Hyponex Merah $3 \mathrm{~g} / \mathrm{l}+$ Tauge $150 \mathrm{~g} / \mathrm{l}$

H: Hyponex Merah $3 \mathrm{~g} / \mathrm{l}+$ Tomat $150 \mathrm{~g} / \mathrm{l}$

I: Hyponex Merah $3 \mathrm{~g} / \mathrm{l}+$ Alpukat $150 \mathrm{~g} / \mathrm{l}$

Masing - masing perlakuan medium pupuk daun ditambah ekstrak pisang $150 \mathrm{~g} / \mathrm{l}$ dan air kelapa $150 \mathrm{ml} / \mathrm{l}$.

Tinggi tanaman yang terbesar terjadi pada minggu ke 3 - 10 pada perlakuan Hyponex merah dengan penambahan ekstrak nabati pisang ambon dan air kelapa. Hal itu terjadi karena pupuk Hyponex merah mempunyai kandungan nitrogen yang tinggi yang dibutuhkan tanaman pada masa vegetatif. Selain itu sitokinin dan auksin yang terdapat pada ekstrak pisang ambon dan air kelapa mempunyai aktifitas dalam merangsang pembelahan sel tanaman. Pertumbuhan tinggi tanaman juga dipengaruhi kandungan karbohidrat yang tinggi pada pisang ambon sebagai sumber karbon dan energi.

Penambahan sari tomat pada pupuk Hypo- 
nex hijau menghasilkan pertumbuhan tinggi tanaman yang lambat. Hal tersebut diduga kandungan zat pengatur tumbuh pada medium tersebut sangat kompleks dan berlebihan untuk pertumbuhan tanaman anggrek. Seperti yang disebutkan oleh Widiastoety (1989) yang menyatakan bahwa zat pengatur tumbuh selain sebagai perangsang dapat pula sebagai penghambat, yang semuanya tergantung pada konsentrasi zat pengatur tumbuh tersebut.

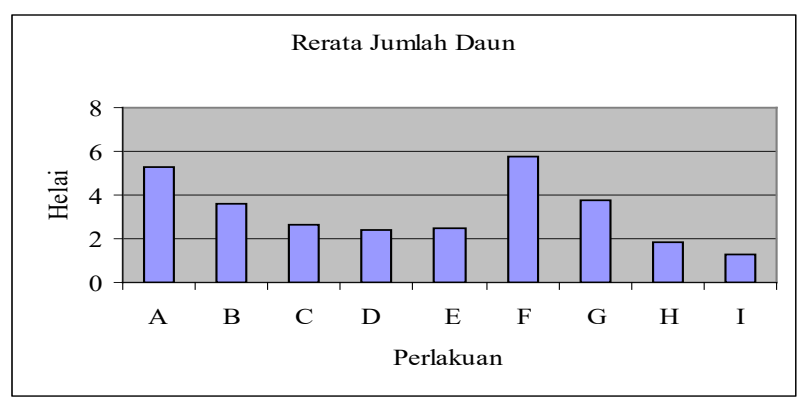

Gambar 3. Histogram Jumlah Daun Anggrek Cattleya pastoral Innocence Umur 10 Minggu

Keterangan:

A: VW + NAA 0,5 ppm + BAP 3 ppm (kontrol) F: Hyponex Merah $3 \mathrm{~g} / \mathrm{l}$

B: Hyponex Hijau $3 \mathrm{~g} / \mathrm{G}$ G: Hyponex Merah $3 \mathrm{~g} / \mathrm{l}+$ Tauge $150 \mathrm{~g} /$

C: Hyponex Hijau $3 \mathrm{~g} / \mathrm{l}+$ Tauge $150 \mathrm{~g} / \mathrm{l} \quad$ H: Hyponex Merah $3 \mathrm{~g} / \mathrm{l}+$ Tomat $150 \mathrm{~g} / \mathrm{l}$

$\begin{array}{ll}\text { D: Hyponex Hijau } 3 \mathrm{~g} / \mathrm{l}+\text { Tomat } 150 \mathrm{~g} / \mathrm{l} & \text { I: Hyponex Merah } 3 \mathrm{~g} / \mathrm{l}+\text { Alpukat } 150 \mathrm{~g} / \mathrm{l}\end{array}$ E: Hyponex Hijau $3 \mathrm{~g} / \mathrm{l}+$ Alpukat $150 \mathrm{~g} / \mathrm{l}$

Masing - masing perlakuan medium pupuk daun ditambah ekstrak pisang $150 \mathrm{~g} / \mathrm{l}$ dan air kelapa $150 \mathrm{ml} / \mathrm{l}$.

Berdasarkan gambar 3. diketahui bahwa perlakuan Hyponex merah + pisang ambon + air kelapa memberikan jumlah daun yang paling banyak. Hal ini berarti medium pupuk daun Hyponex merah dengan penambahan ekstrak nabati pisang ambon dan air kelapa mampu menggantikan medium VW pada subkultur anggrek Cattleya pastoral innocence karena dapat merangsang pertumbuhan dan perkembangan jumlah daun yang lebih banyak

Kandungan nitrogen dalam pupuk daun Hyponex merah lebih tinggi (25:5:20) dibandingkan dengan pupuk daun Hyponex hijau (20:20:20). Dengan demikian jumlah nitrogen yang diserap oleh tanaman lebih banyak pada medium pupuk daun Hyponex merah dibanding pada Hyponex hijau.

Perlakuan Hyponex merah dengan kombinasi ekstrak nabati berupa pisang ambon, air kelapa dan alpukat mempunyai pertumbuhan jumlah daun yang paling sedikit. Hal ini berkaitan dengan kemampuan tanaman dalam mengadsorpsi terhadap nutrisi dan zat pengatur pumbuh. Ekstrak alami yang diberikan terlalu banyak dan kandungan lemak yang tinggi pada alpukat menyebabkan sintesis protein berjalan lebih lambat karena tidak dapat langsung diserap oleh tanaman.

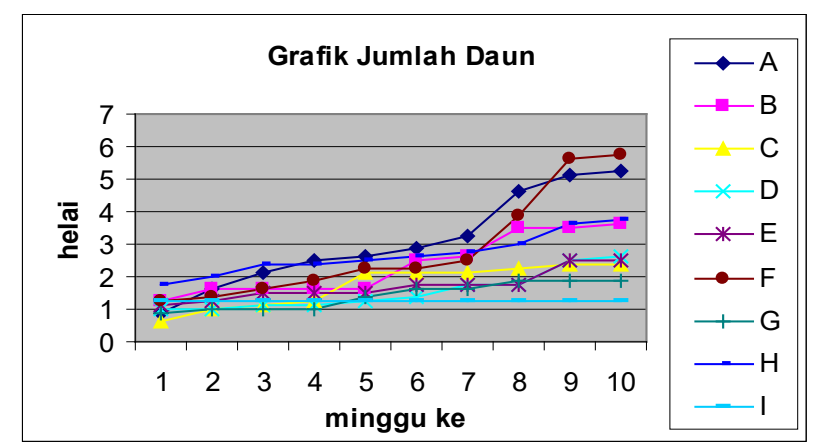

Gambar 4. Grafik Jumlah Daun Anggrek Cattleya pastoral Innocence selama 10 Minggu

Keterangan:

A: VW + NAA 0,5 ppm + BAP 3 ppm (kontrol) F: Hyponex Merah $3 \mathrm{~g} / \mathrm{l}$

B: Hyponex Hijau $3 \mathrm{~g} / \mathrm{l} \quad$ G: Hyponex Merah $3 \mathrm{~g} / \mathrm{l}+$ Tauge $150 \mathrm{~g} / \mathrm{l}$

$\begin{array}{ll}\text { C: Hyponex Hijau } 3 \mathrm{~g} / \mathrm{l}+\text { Tauge } 150 \mathrm{~g} / \mathrm{l} & \text { H: Hyponex Merah } 3 \mathrm{~g} / \mathrm{l}+\text { Tomat } 150 \mathrm{~g} / \mathrm{l}\end{array}$

D: Hyponex Hijau $3 \mathrm{~g} / \mathrm{l}+$ Tomat $150 \mathrm{~g} / \mathrm{l} \quad \mathrm{I}$ : Hyponex Merah $3 \mathrm{~g} / \mathrm{l}+$ Alpukat $150 \mathrm{~g} / \mathrm{l}$

E: Hyponex Hijau $3 \mathrm{~g} / \mathrm{l}+$ Alpukat $150 \mathrm{~g} / \mathrm{l}$

Masing - masing perlakuan medium pupuk daun ditambah ekstrak pisang $150 \mathrm{~g} / \mathrm{l}$ dan air kelapa $150 \mathrm{ml} / \mathrm{l}$.

Berdasarkan gambar 4 dapat dilihat bahwa jumlah daun mengalami peningkatan pada minggu ke 2 sampai minggu terakhir. Pemberian ekstrak nabati pisang ambon dan air kelapa pada medium pupuk daun Hyponex merah memberikan peningkatan jumlah daun yang paling besar. Peningkatan cenderung stabil sampai minggu ke7 dan peningkatan jumlah daun paling besar terjadi pada minggu ke 8 . Hal ini karena tanaman anggrek sudah mampu beradaptasi dan 
menyerap unsur hara dan hormon alami dalam ekstrak pisang ambon dan air kelapa yang dapat memacu perkembangan daun.

Penambahan ekstrak alpukat pada medium Hyponex merah mempunyai pertambahan jumlah daun yang paling rendah. Hal ini berkaitan dengan kemampuan jaringan tanaman dalam mengadsorpsi nutrisi dan zat pengatur tumbuh. Ekstrak alami yang diberikan terlalu banyak menyebabkan zpt pada medium terlalu tinggi dan adanya lemak pada alpukat menyebabkan nutrisi sulit dicerna anggrek Cattleya pastoral innocence.

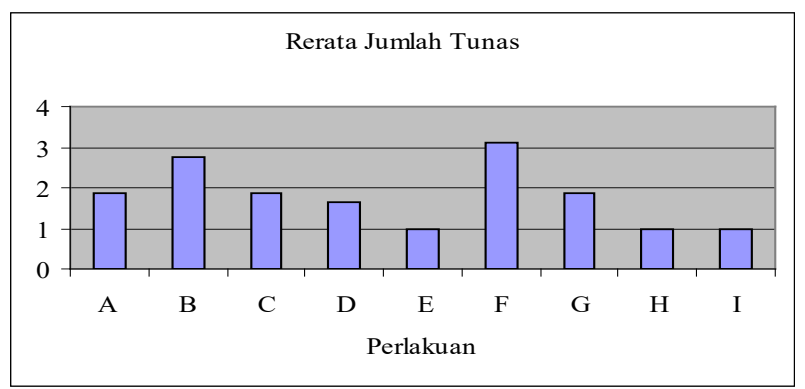

Gambar 5. Histogram Jumlah Tunas Anggrek Cattleya pastoral Innocence Umur 10 Minggu

Keterangan:

A: VW + NAA 0,5 ppm + BAP 3 ppm (kontrol) F: Hyponex Merah $3 \mathrm{~g} /$

B: Hyponex Hijau $3 \mathrm{~g} / \mathrm{l} \quad$ G: Hyponex Merah $3 \mathrm{~g} / \mathrm{l}+$ Tauge $150 \mathrm{~g} / \mathrm{l}$

C: Hyponex Hijau $3 \mathrm{~g} / \mathrm{l}+$ Tauge $150 \mathrm{~g} / \mathrm{H} \quad \mathrm{H}$ : Hyponex Merah $3 \mathrm{~g} / \mathrm{l}+$ Tomat $150 \mathrm{~g} / \mathrm{l}$

D: Hyponex Hijau $3 \mathrm{~g} / \mathrm{l}+$ Tomat $150 \mathrm{~g} / \mathrm{l} \quad \mathrm{I}$ : Hyponex Merah $3 \mathrm{~g} / \mathrm{l}+$ Alpukat $150 \mathrm{~g} /$

E: Hyponex Hijau $3 \mathrm{~g} / \mathrm{l}+$ Alpukat $150 \mathrm{~g} / \mathrm{l}$

Masing - masing perlakuan medium pupuk daun ditambah ekstrak pisang $150 \mathrm{~g} / \mathrm{l}$ dan air kelapa $150 \mathrm{ml} / \mathrm{l}$.

Rerata jumlah tunas yang terbentuk pada minggu 10 (gambar 5) menunjukan bahwa perlakuan Hyponex merah yang ditambahkan pisang ambon $150 \mathrm{~g} / \mathrm{l}$ dan air kelapa $150 \mathrm{ml} / 1$ menghasilkan jumlah tunas terbanyak dibandingkan perlakuan yang lain. Unsur hara yang terdapat pada Hyponex merah mendukung pertumbuhan tunas. Selain itu auksin dan sitokinin yang terdapat pada pisang dan air kelapa sudah mampu meningkatkan jumlah tunas. Sedangkan pada perlakuan yang ditambahkan 3 macam ekstrak nabati justru menghasilkan jumlah tunas yang rendah. Ini diakibatkan konsentrasi zpt pada medium terlalu tinggi sehingga bersifat toksik bagi tanaman anggrek Cattleya pastoral innocence.

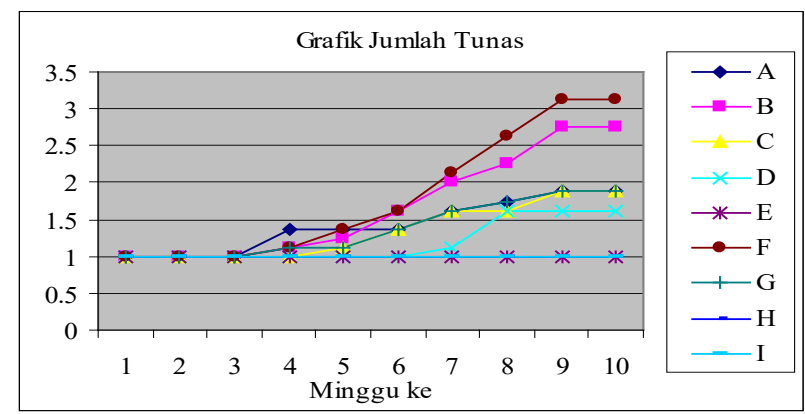

Gambar 6. Grafik Jumlah Tunas Anggrek Cattleya pastoral Innocence selama 10 Minggu

Keterangan:

A: VW + NAA 0,5 ppm + BAP 3 ppm (kontrol) F: Hyponex Merah $3 \mathrm{~g} / \mathrm{l}$

$\begin{array}{ll}\text { B: Hyponex Hijau } 3 \mathrm{~g} / \mathrm{l} & \text { G: Hyponex Merah } 3 \mathrm{~g} / \mathrm{l}+\text { Tauge } 150 \mathrm{~g} / \mathrm{l} \\ \text { C: Hyponex Hijau } 3 \mathrm{~g} / \mathrm{l}+\text { Tauge } 150 \mathrm{~g} / \mathrm{l} & \text { H: Hyponex Merah } 3 \mathrm{~g} / \mathrm{l}+\text { Tomat } 150 \mathrm{~g} / \mathrm{l}\end{array}$

D: Hyponex Hijau $3 \mathrm{~g} / \mathrm{l}+$ Tomat $150 \mathrm{~g} / \mathrm{l} \quad$ I : Hyponex Merah $3 \mathrm{~g} / \mathrm{l}+$ Alpukat $150 \mathrm{~g} / \mathrm{l}$

E: Hyponex Hijau $3 \mathrm{~g} / \mathrm{l}+$ Alpukat $150 \mathrm{~g} / \mathrm{l}$

Masing - masing perlakuan medium pupuk daun ditambah ekstrak pisang $150 \mathrm{~g} / \mathrm{l}$ dan air kelapa $150 \mathrm{ml} / \mathrm{l}$.

Berdasarkan gambar 6. dapat dilihat bahwa perlakuan Hyponex merah dengan penambahan ekstrak nabati pisang ambon dan air kelapa memberikan peningkatan jumlah tunas yang paling besar dan mulai mengalami peningkatan jumlah tunas mulai minggu ke 4. Hormon auksin dan sitokinin yang terdapat pada ekstrak pisang ambon dan air kelapa mempunyai aktifitas dalam memacu pertumbuhan tunas. Selain zat pengatur tumbuh, karbohidrat juga mempunyai peranan yang sangat penting untuk memacu pertumbuhan tanaman. Hal ini terjadi karena dalam ekstrak pisang ambon mempunyai kandungan kalori dan karbohidrat yang tinggi.

Pada perlakuan Hyponex hijau dengan penambahan alpukat dan perlakuan Hyponex merah yang ditambahkan sari tomat dan alpukat justru tidak mengalami peningkatan jumlah tunas. Hal ini berkaitan dengan kemampuan tanaman untuk beradaptasi dengan medium yang baru dimana sebagian tanaman pada per- 
lakuan tersebut mengalami pencoklatan sehingga pertumbuhannya terhenti dan tidak mampu membentuk tunas.

\section{Persentase Browning dan Warna Daun}

Pengamatan warna daun dilakukan seminggu sekali dengan menggunakan Munsell Plant Tissue Colour Chart. Pengamatan warna daun ini dilakukan untuk mengetahui adanya perubahan warna pada daun sebagai akibat respon tanaman terhadap penggunaan jenis pupuk daun dan berbagai macam ekstrak alami. Pengamatan persentase browning dilakukan dengan menghitung tanaman yang mengalami browning pada masing-masing perlakuan. Persentase browning dan warna daun pada tanaman anggrek Cattleya pastoral innocence pada umur 10 minggu tersaji pada tabel 2 .

Tabel 2. Persentase Browning dan Warna Daun Anggrek Cattleya pastoral Innocence Umur 10 Minggu

\begin{tabular}{|c|c|c|c|c|}
\hline \multirow{2}{*}{ Perlakuan } & \multirow{2}{*}{$\begin{array}{c}\% \\
\text { Browning }\end{array}$} & \multicolumn{3}{|c|}{ Warna Daun } \\
\hline & & Kategori & Keterangan & Skor \\
\hline $\begin{array}{l}\text { Vacin \& Went + NAA } 0.5 \text { ppm + } \\
\text { BAP } 3 \text { ppm }\end{array}$ & 0 & $5 \mathrm{GY} 6 / 8$ & hijau muda & +++ \\
\hline $\begin{array}{l}\text { Hyponex Hijau + Pisang + Air } \\
\text { Kelapa }\end{array}$ & 25 & $5 \mathrm{GY} 6 / 8$ & hijau muda & +++ \\
\hline $\begin{array}{l}\text { Hyponex Hijau + Pisang + Air } \\
\text { Kelapa + Tauge }\end{array}$ & 37,5 & $5 \mathrm{GY} 6 / 8$ & hijau muda & +++ \\
\hline $\begin{array}{l}\text { Hyponex Hijau + Pisang + Air } \\
\text { Kelapa + Tomat }\end{array}$ & 75 & 2,5 Y $8 / 4$ & coklat muda & - \\
\hline $\begin{array}{l}\text { Hyponex Hijau + Pisang + Air } \\
\text { Kelapa + Alpukat }\end{array}$ & 87,5 & 2,5 Y $8 / 2$ & coklat muda & - \\
\hline $\begin{array}{l}\text { Hyponex Merah + Pisang + Air } \\
\text { Kelapa }\end{array}$ & 25 & 5 GY 5/8 & hijau tua & ++++ \\
\hline $\begin{array}{l}\text { Hyponex Merah + Pisang + Air } \\
\text { Kelapa + Tauge }\end{array}$ & 37,5 & $5 \mathrm{GY} 6 / 8$ & hijau tua & +++ \\
\hline $\begin{array}{l}\text { Hyponex Merah + Pisang + Air } \\
\text { Kelapa + Tomat }\end{array}$ & 75 & 2,5 Y $8 / 2$ & coklat muda & - \\
\hline $\begin{array}{l}\text { Hyponex Merah + Pisang + Air } \\
\text { Kelapa + Alpukat }\end{array}$ & 87,5 & 2,5 Y $8 / 2$ & coklat muda & - \\
\hline
\end{tabular}

Keterangan: Jumlah $(+)$ semakin banyak menunjukan tanaman lebih hijau.

Pada perlakuan Vacin \& Went tidak ada tanaman yang mengalami browning. Hal ini disebabkan pemberian zat pengatur tumbuh NAA dan BAP yang seimbang dalam medium VW, dimana BAP mempunyai aktifitas dalam pembentukan klorofil. Selain itu diduga tanaman lebih mudah beradaptasi pada medium baru, karena pada subkultur sebelumnya medium yang digunakan adalah medium VW.

Pada medium pupuk daun Hyponex hijau maupun merah, pemberian ekstrak nabati pisang ambon dan air kelapa mengalami browning yang paling rendah dibandingkan penambahan ekstrak nabati lainnya pada medium pupuk daun. Hal ini disebabkan karena bahan organik yang diberikan tidak terlalu kompleks sehingga lebih mudah diserap oleh tanaman. Hal ini sesuai dengan pendapat Santoso (2001) yang menyatakan bahwa dengan mengurangi karbohidrat medium akan mengurang agen yang menyebabkan terjadinya pencoklatan.

Pemberian ekstrak alpukat pada medium pupuk daun Hyponex hijau dan merah mengalami browning paling tinggi diikuti medium pupuk daun yang ditambahkan sari tomat (tabel 2). Hal ini disebabkan oleh ketidakmampuan tanaman beradaptasi dengan medium yang baru sehingga tanaman akan berwarna coklat pada sebagian atau seluruh organ tanaman.

Kandungan lemak yang terdapat pada buah alpukat, selain sulit dicerna oleh tanaman untuk pertumbuhannya juga akan menyebabkan oksidasi lemak yang mempunyai pengaruh racun seperti peroksida asam lemak yang dapat merusak vitamin terlarut dan menurunkan mutu protein. Coumarin yang terdapat dalam tomat meningkatkan oksidasi fenol yang justru akan menghambat pembelahan sel dan membuat tanaman berwarna coklat.

Berdasarkan tabel 2 diketahui bahwa pada perlakuan Hyponex merah dengan ekstrak nabati pisang + air kelapa menunjukan warna daun yang lebih hijau dibandingkan dengan perlakuan yang lain. Pengaruh unsur nitrogen dalam Hyponex merah yang tinggi sangat dibutuhkan dalam pembentukan hijau daun. nitrogen akan menaikan daya tumbuh tanaman dalam pembentukan 
klorofil, asam amino dan hormon tumbuh. Selain itu adanya kandungan karbohidrat yang tinggi pada pisang menyebabkan warna yang terbentuk lebih hijau dan adanya hormon sitokinin dan auksin alami pada pisang dan air kelapa mempengaruhi warna hijau daun. Hal ini sesuai dengan Dwijoseputro (1994) yang menyatakan bahwa terbentuknya klorofil dipengaruhi oleh karbohidrat terutama dalam bentuk gula. nitrogen merupakan bahan inti pembentukan klorofil yang diperlukan dalam jumlah yang cukup. Kandungan nitrogen yang terdapat pada $\mathrm{Hy}$ ponex merah mempunyai perbandingan unsur $\mathrm{N}$ yang lebih besar dibanding pupuk Hyponex hijau. Selain itu pengaruh sitokinin yang kuat dalam medium mampu memacu pembentukan kloroplas, dan klorofil akan menjadi lebih stabil akibat adanya pembentukan protein yang akan meningkat.

Perlakuan VW dengan penambahan zat pengatur tumbuh NAA 0.5 ppm dan BAP 3 ppm mempunyai warna daun hijau muda. Zat pengatur tumbuh terutama sitokinin dalam bentuk BAP yang terdapat dalam medium VW dapat memacu perkembangan kloroplas dan meningkatkan laju sintesis protein sehingga klorofil lebih stabil. Warna daun pada medium VW sama dengan perlakuan Hyponex hijau yang ditambahkan pisang ambon dan air kelapa serta pada perlakuan medium pupuk Hyponex hijau dan merah yang ditambahkan tauge.

Pemberian tomat memberikan warna daun coklat muda disebabkan coumarin yang terdapat pada tomat yang menghambat pertumbuhan, selain itu kadar auksin yang tinggi pada tomat akan menghambat pembentukan klorofil. Pencoklatan juga terjadi pada medium pupuk daun dengan penambahan alpukat. lemak yang tinggi pada medium mengakibatkan tanaman sulit mencerna dan adanya oksidasi lemak mempunyai pengaruh racun sehingga warna daun men- jadi coklat. Selain itu ZPT eksogen yang diberikan terlalu banyak sehingga medium tidak sesuai untuk pertumbuhan tanaman anggrek Cattleya pastoral innocence

\section{SIMPULAN}

Hasil penelitian dari penggunaan pupuk daun dan ekstrak nabati terhadap subkultur anggrek Cattleya pastoral innocence secara in vitro pada berbagai parameter dapat disimpulkan bahwa 1) Medium pupuk daun dan ekstrak ekstrak nabati mampu menggantikan medium Vacin \& Went terhadap tinggi tanaman dan jumlah tunas 2) Medium pupuk daun Hyponex hijau dan merah memberikan pengaruh yang cenderung sama terhadap tinggi tanaman, jumlah daun dan jumlah tunas anggrek Cattleya pastoral innocence 3) Medium pupuk daun Hyponex merah $3 \mathrm{~g} / \mathrm{l}$ dan ekstrak pisang ambon $150 \mathrm{~g} / 1$ dan air kelapa $150 \mathrm{~g} / \mathrm{l}$ memberikan pengaruh yang lebih baik dibanding perlakuan lain terhadap tinggi tanaman, jumlah daun dan jumlah tunas.

Dari hasil penelitian penulis dapat menyarankan perlu dilakukan penelitian lebih lanjut mengenai pengunaan pupuk daun Hyponex merah $3 \mathrm{~g} / \mathrm{l}+$ pisang ambon $150 \mathrm{~g} / \mathrm{l}+$ air kelapa $150 \mathrm{ml} / \mathrm{l}$ untuk jenis anggrek yang lain.

\section{DAFTAR PUSTAKA}

Anonim. 2002. Anggrek : Bunga dengan Aneka Pesona Bentuk dan Warna. Agro Media Pustaka. Jakarta. , 2004. Anggrek Import Serbu Pasar Lokal. http:Illwww. suaramerdeka.com/harian/0409/17/ekonomi 09.htm

Dwidjoseputro. 1994. Pengantar Fisiologi Tumbuhan. Gramedia Pustaka Utama. Jakarta.

Hendaryono. 1996. Tehnik Kultur Jaringan. Penerbit Kanisius. Yogyakarta.

Santoso, U. 2001. Kultur Jaringan Tanaman. Universitas Muhammadiyah Malang

Wattimena,G.A. 1992. Bioteknologi Tanaman. Institut Pertanian Bogor. Bogor

Widiastoety, D dan Syafril. 1989. Kultur in Vitro Dendrabium Ekapol No 1 Dalam Medium Cair. Buletin Penelitian Holtikultura Vol .XVIII No.3. 